This is a self-archived version of an original article. This version may differ from the original in pagination and typographic details.

Author(s): Ursin, Jani; Paloniemi, Susanna

Title: Conceptions of teachership in the professional identity construction of adult educator graduates

Year: 2019

Version: Accepted version (Final draft)

Copyright: (c) Taylor \& Francis, 2019.

Rights: In Copyright

Rights url: http://rightsstatements.org/page/InC/1.0/?language=en

Please cite the original version:

Ursin, J., \& Paloniemi, S. (2019). Conceptions of teachership in the professional identity construction of adult educator graduates. Teacher Development, 23(2), 233-248.

https://doi.org/10.1080/13664530.2019.1575274 


\title{
Conceptions of Teachership in the Professional Identity Construction of Adult Educator Graduates
}

\author{
Jani Ursin ${ }^{\mathrm{a}^{*}}$ and Susanna Paloniemi ${ }^{\mathrm{b}}$ \\ aFinnish Institute for Educational Research, University of Jyväskylä, Jyväskylä, \\ Finland; 'Department of Educational Sciences, University of Jyväskylä, Jyväskylä, \\ Finland \\ Jani Ursin \\ Finnish Institute for Educational Research, University of Jyväskylä, Jyväskylä, Finland \\ P.O. Box 35 \\ FI-40014 University of Jyväskylä
}

FINLAND

Tel. +358503030811

Email. jani.p.ursin@j.jyu.fi

http://orcid.org/0000-0001-6557-9058

Susanna Paloniemi

Department of Educational Sciences, University of Jyväskylä, Jyväskylä, Finland

P.O. Box 35

FI-40014 University of Jyväskylä

FINLAND 
Tel. +358408053646

Email. susanna.paloniemi@jyu.fi

http://orcid.org/0000-0002-5591-6353

Jani Ursin, $\mathrm{PhD}$, is a senior researcher at the Finnish Institute for Educational Research of the University of Jyväskylä, Finland. He holds the Title of Docent in Higher Education Research. His research has focused on quality assurance in higher education, mergers of Finnish universities, learning outcomes in higher education, and academic work and identities. Ursin is on the editorial board of several journals in the field of higher education.

Susanna Paloniemi, $\mathrm{PhD}$, is a senior lecturer at the Department of Education of the University of Jyväskylä, Finland. Her research has focused on professional identity, agency, leadership practices, and work-related learning in the domains of health care, education, and information technology. She is currently working on the Role of Emotions in Agentic Learning (REAL) research project. Her recent publications include articles in Professional Development in Education, Educational Research Review, and Management Learning. Paloniemi is co-editor of a volume on Agency at Work, in the Springer Series on Professional and Practice-Based Learning. 


\section{Conceptions of Teachership in the Professional Identity Construction of Adult Educator Graduates}

The aim of this study was to investigate the conceptions of teachership among graduates $(\mathrm{n}=126)$ from a Finnish higher education study programme called Pedagogical Studies for Adult Educators (PSAE). The conceptions of teachership comprise notions of teaching and of oneself as a teacher. Accordingly, the conceptions of teachership are viewed as one element in the process of constructing teacher identity. Currently we have little knowledge about the professional identity construction of adult educators, even though there is a growing need for adult pedagogics in the changing professional life. Based on a qualitative thematic analysis of open-ended questionnaire data, three main conceptual categories were identified: 1) teachership as an activity, 2) teachership as a personal disposition, and 3) teachership as a process. It was concluded that in studying teacher identity it is essential to focus on the interplay between the personal and the social. Thus, the findings suggest that in understanding and supporting the construction of teacher identities, one should pay particular attention to the intertwined relationship between individual and collective needs.

Keywords: teachership; teacher identity; adult educators; adult education; teacher training programme; conceptions of teaching 


\section{Introduction}

In all educational sectors, teaching is currently facing challenges. The everyday lives of teachers have been affected by a diversifying student population, and by demands for more versatile teaching methods (e.g. Livingston 2017). In the fields of adult, vocational, and higher education, requirements for lifelong learning have demanded new kinds of professional expertise among teachers, in an era when the relationship between education, work, and society is becoming blurred (Green 2002). In parallel with this, educational organisations face structural challenges and demands for increased productivity, often accompanied by a decrease in the resources available (e.g. Brehony \& Deem 2005). For professionals working in the domain of adult education, the challenges touch upon the core meanings attached to work (e.g. Siivonen et al. 2016). Moreover, changes in the contents and processes of the work are taking place with new conceptions and premises related to teaching as a profession. Thus, it is appropriate to ask what kind of professional identity can meet these various expectations, and how adult educators view their teachership in this changing environment.

The aim of the present study was to investigate the core of adult educators' professional identity after their one-year higher education study programme called Pedagogical Studies for Adult Educators (PSAE). Professional identity is approached here through the conceptions of teachership, which comprise the PSAE graduates' notions of teaching and of themselves as teachers. It seems highly likely that these conceptions of teachership form a central part of teacher identity, with much of the process of identity construction taking place during educational studies. Ultimately, 
one can expect that conceptions of teachership, and the identities thereby formed, will influence the quality of teaching and learning in various professional contexts.

Questions of how teachers view themselves as teachers, and of the kinds of teaching conceptions they possess, have been studied, in particular, from the point of view of the teacher-student relationship (e.g. Samuelowicz \& Bain 1992, 2001; Trigwell, Prosser \& Waterhouse 1999). Nevertheless, the studies in question have paid little attention to the sociocultural contexts of teaching practices. More recently, however, the focus has shifted more widely onto teachers' professional identity (e.g. Beijaard, Meijer \& Verloop 2004; Davey 2013; Toom, Pyhältö \& Rust 2015; Vähäsantanen \& Billett 2008), considered in relation to the structural changes taking place in the educational domain (e.g. Ketelaar, Beijaard, Boshuizen \& den Brok 2012; Rajala \& Kumpulainen 2017; Vähäsantanen 2015).

In recent years, research on professional identity has greatly increased, with the teaching profession being one of the most studied domains (e.g. Eteläpelto et al. 2014; Toom, Pyhältö \& Rust 2015). However, the majority of the studies conducted have dealt with the identity of teachers working in school contexts. Much less attention has been paid to the professional field of adult education or to the professional identity construction of adult educators. Consequently, there is a lack of research on adult educators' conceptions of teaching and of themselves as teachers, or on the core meanings of their professional identity and identity construction within their educational studies. Thus, the present study contributes to research into professional identity in the field of adult education through investigating PSAE graduates' conceptions of teachership and looking at professional identity from various perspectives including personal dispositions and activities involved. 
This paper touches on the constructions of teacher identity that appeared to arise from conceptions of teachership adopted during a one-year study programme devised for adult educator students. We viewed the PSAE graduates' conceptions of teaching and of themselves as teachers as likely to exert a strong influence on their professional identity and their understanding of teachership - as elements that would be further developed and negotiated within their work communities.

\section{Conceptual Framework}

\section{Teachers' Professional Identity}

Professional identity is a multifaceted concept, and one that has been used in numerous ways in research. On the basis of a review, Beijaard, Meijer and Verloop (2004) suggested that research on teachers' professional identity can be divided into three categories. The first category consists of studies in which the focus is on teachers' professional identity formation. Most of the research conducted so far has concentrated on identity formation and its relation to teacher training. The second category encompasses studies with a focus on what the professional identity of a teacher actually consists of. In these studies a range of different topics have been investigated, such as teachers' perceptions and roles. The third category is formed by studies in which professional identity is (re)presented by teacher narratives. This line of research has aroused minor but growing interest over recent years.

In their review, Beijaard and colleagues (2004) suggest that professional identity has four necessary features: (i) it is an ongoing process, (ii) it implies both a person and a context, (iii) it consists of sub-identities, and (iv) it contains agency as an important element. According to this view, professional identity is not something that 
teachers have, but rather something that they use in making sense of themselves professionally and personally. Professional identity is an outcome of, and is entangled with the interaction between personal, cultural, social, and institutional domains (van den Berg 2002).

In theoretical terms, research on professional identity has primarily been based on the sociocultural theory of learning, in which professional identity is seen as constructed through participation in authentic working-life contexts (Wenger 1998). However, within this framework, the concept of identity has often been replaced by a cognitively-oriented concept of expertise. Eteläpelto and Vakiala (2004) argue that a definition of professional identity that relies heavily on the competencies needed overlooks individual subjectivities, and their role in the community.

In a similar manner, Flores and Day (2006; see also Talbert \& McLaughlin 1996) consider teacher's professional identity to be dependent on teachers' views of themselves and of the contexts in which they act as teachers. The individual's past is present in making sense of the purpose of teaching and being a teacher. Davey (2013) has synthesised the various aspects of teacher's professional identities as exhibiting group membership and affinity, motivation and aspiration, a job description and activity, knowledge and expertise, and the personal within the professional (involving e.g. personal qualities and emotionality).

Another concept suggested in professional identity research has been that of subjectivity, which gives more space to individual subjects and emotions as part of the negotiation process. Within a subject-centred sociocultural framework (Billett, Harteis \& Eteläpelto 2008; Eteläpelto, Vähäsantanen, Hökkä \& Paloniemi 2013), subjectivity 
and agency have been emphasised as maintaining a balance between the self and cultural practices.

Despite the increase in research on teacher identity, the notion of identity is a relatively new one in the field of professional learning research (Eteläpelto et al. 2014). The major stream in professional learning within the teaching profession has approached learning from the viewpoint of professional competences and skills. Nevertheless, research on teachers' professional identity has highlighted the social and emotional aspects of learning as a central element in professional learning. It is argued that professional identity can be understood as an ongoing, relational, emotionally imbued, and culturally determined process of defining and redefining oneself as a professional subject (Eteläpelto et al. 2014). Accordingly, professional identity is composed of an individual's life-historical conception of herself/himself as a professional actor. Within this broad conception, professional values, ethics, and beliefs are combined with the individual's conceptions of what constitutes valuable and rewarding work (Vähäsantanen 2015). Along similar lines, Flores and Day (2006, 220) define identity as 'an ongoing and dynamic process which entails the making sense and (re)interpretation of one's own values and experiences. Becoming a teacher involves, in essence, the (trans)formation of [...] teacher identity.'

In the present study we lean on sociocultural understandings of professional identity. In other words, we see professional identity as constantly constructed in a manner involving professional and personal subjectivity. The construction involves the interweaving of past and present in a particular cultural context; hence, the identity is situationally constituted and negotiated (e.g. Eteläpelto et al. 2014). Thus, we stress the two elements presented by Beijaard and colleagues (2004), namely the interaction 
between person and context, and the importance of agency in developing professional identity (see also Ruohotie-Lyhty \& Moate 2016).

The notion of agency comes close to the sociocultural notion of participation, which emphasises the activities and processes involved in becoming a member of a given community. This view highlights that learning is inextricably bound up with identity formation (ten Dam \& Blom 2006). It has been argued that belonging to an authentic professional community constitutes the most important resource for novice teachers in constructing their professional identity (e.g. Eteläpelto \& Vakiala 2004; ten Dam \& Blom 2006).

Research on the socialisation process of real-world teaching supports the central importance of making sense of events, within a context that is influenced by personal beliefs, values, and life histories (Leshem 2008), as well as by the nature of the local teacher community (Talbert \& McLaughlin 1996). Furthermore, the sociocultural paradigm stresses the interaction between individuals as they utilise culturally, socially, and historically determined resources. This utilisation also forms part of the notion of teachership, which according to Lasky $(2005,900)$ 'shapes and is shaped by the structural and cultural features of society and school cultures.' In the next section we focus on the conceptions of teaching which we understand as central elements of teachership.

\section{Conceptions of Teaching}

Conceptions can be understood as including the personal and emotional meanings of the cultural and social legacies of everyday knowledge (cf. Entwistle \& Walker 2000). Previous studies on the conceptions of teaching and learning seem to have focused mainly on the teacher-student relationship (e.g. Entwistle \& Walker 2000; 
Samuelowicz \& Bain 1992, 2001; Trigwell, Prosser \& Waterhouse 1999) and on reflection on teaching practices (e.g. Brookfield 1995; Trigwell et al. 2000).

Accordingly, teaching has been seen as a reflective process in which teachers construct their professional identity, especially in relation to the self and the students. Although the studies in question do stress the relational nature of teaching conceptions, they have not focused very strongly on the broader sociocultural context (involving colleagues and networks, for example).

With respect to the teacher-student relationship, Kember (1997) has proposed a synthesis of conceptions on teaching. He distinguishes two broad orientations. The first orientation is teacher-centred, focusing on the knowledge and communication of the teacher. The second orientation is student-centred, concentrating on the knowledge of the students rather than that of the teacher. Within the latter orientation, teaching is seen more as a means of facilitating students' understanding, conceptual change and intellectual development, rather than that of sharing information. This view was also present in an earlier paper by Murray and Macdonald (1997), who noted that the main conceptions of (university) teaching are those of providing and facilitating student support. However, these studies have focused on dyadic relationships between teachers and students, while paying less attention to the wider contexts and communities in which both teachers and students are involved.

Reality does not always correspond to the ideal conceptions of teaching. Samuelowicz and Bain $(1992,110)$ distinguished the ideal from the working conceptions of teaching, noting that 'the aims of teaching expressed by (academic) teachers coincide with the "ideal" conception of teaching whereas their teaching practices reflect their working conception of teaching'. Similarly Murray and 
Macdonald (1997) observed a disjunction between lecturers' conceptions of teaching and their claimed educational practice. Entwistle and Walker (2000) have pointed to the need to expand teachers' awareness of learning and teaching in order to encourage reflection on professional knowledge. More recently, Wall's (2016) longitudinal study on early career teachers' educational beliefs on teaching and learning evidenced a common progression: from idealism toward cognitive dissonance and a search for an authentic teaching persona, and finally towards the construction of a personal identity as a teacher. Thus, conceptions and beliefs concerning teaching, one's own role as a teacher, educational practices and relationships with others (i.e. students and colleagues) form an essential part of the teaching profession and of the development of one's teachership. Consequently, one's teaching conceptions, as means of moving towards teacher identity, are context-dependent, reshaped throughout one's professional career, and closely intertwined with commitments, values, identifications, and group membership. In this way, professional identity is also influenced by a shared understanding formed within work communities (see e.g. Hökkä, Vähäsantanen \& Mahlakaarto 2017).

To sum up, we understand the notion of teachership as being constructed in the process of developing a professional (teacher) identity, i.e. the process within which one's conceptions of teaching and of oneself as a professional teacher are formulated. This process comprises at the same time personal, professional, and contextual elements. Note here that teacher identity and conceptions of teaching can be conflicting: the teacher can have an ideal picture of what 'good teaching' is, but in practice $\mathrm{s} /$ he might not be able to act accordingly. The situatedness of professional identity construction thus means that one needs to develop certain ways of working 
within one's current work community. Consequently, changing environments and situations pose challenges for continuous learning and for the (re)constructions of professional identity. The question is not merely about how subjects learn their work tasks and work practices, but also about how the professionals learn things about themselves, especially in terms of how they reconstruct their professional identity and promote their agency and subjectivity at work. In the present study the PSAE graduates' conceptions of teachership were understood as one element in the construction of their professional teacher identity - a construction that would be subjected to further situational development and negotiation in their respective work communities.

\section{Aims, Data and Analysis}

\section{Aim of the Study and Research Tasks}

The aim of the study was to shed light on the construction of professional identity among adult educator graduates in Finland. Hence, we investigated their conceptions of teachership, consisting of their notions of teaching and of themselves as teachers. The research question posed is framed as follows: What conceptions do adult educator graduates have of teachership (i.e. of teaching, and of themselves as teachers)?

\section{Data and Analysis}

The study was conducted as a part of a larger research project investigating the changing roles of adult educators in Finland (see Pakkanen 2006). The purpose of the research project was, in the first place, to evaluate one-year Pedagogical Studies for Adult Educators (PSAE) and, secondly, to investigate the everyday practices of adult educators working in different educational settings. More specifically, the project 
investigated the roles of adult educators and their position in the labour market with regard to changes in the world of work and the contents of their daily work practices. Consequently, for the purposes of the larger research project a survey design was chosen and a questionnaire was implemented as a means for data collection. Resorting to a survey was justified also by practical reasons: it was the most feasible way to reach the participants scattered across Finland.

A questionnaire was sent to all PSAE graduates $(\mathrm{N}=199)$ who had completed the programme during the academic years 2002-2004. The questionnaires were sent personally and directly to all respondents, making it clear that participation was fully voluntary and the anonymity of participants was guaranteed. A total of 136 filled questionnaires were returned (response rate 68\%) of which 109 by females and 27 by males. For the purposes of the study reported here we used the data from an openended question, which asked the participants to describe their own conceptions of teachership. The item was formulated as follows: During your teacher training - and probably afterwards as well-you have given thought to the question of teachership. How would you describe your own teachership? The concept of teachership was selected on the basis of familiarity as the participants had reflected their own teachership throughout the PSAE programme. Altogether 126 respondents answered the question.

The data was analysed by means of thematic analysis (Braun \& Clarke 2006). First of all, from the answers similar notions depicting the respondents' conceptions of teachership were coded under preliminary categories (the identification phase). This coding was done separately by the two authors. Secondly, we compared the preliminary categories created in the identification phase. This second phase led to 
some redefining and renaming of the categories. Finally, the preliminary categories were further elaborated on the basis of both theory and quantitative differences, resulting in the final categories (the selection phase).

\section{Participants}

All respondents had finished their PSAE training, which includes components on the principles of learning at work, dialogue, and experiential learning (see also Arvaja 2018). This encourages the trainees to form their own personal pedagogical thinking in relation to their experiences as teachers. The PSAE study programme as a whole (60 ECTS) includes nine contact sessions of two days at minimum. The first day is typically introductory in nature (consisting of lectures) while the second day is dedicated to group work (around ten students per group) on a learning assignment. Each group is led by an experienced tutor. The trainees write their personal study plans (PSPs) on the basis of discussions with their tutor and the work done in the groups.

Throughout the study programme, the trainees keep a weekly learning diary to be read by the tutor. They also video record their teaching at two occasions during the training, and these recordings are analysed and discussed in the learning group. The trainees also observe teaching and learning situations that are totally new to them. Finally, they write down their learning philosophy, within which they include basic principles regarding their approach to teaching, and their conceptions of teaching. Referring mainly to this document, they engage in an evaluation discussion with their tutors.

Most of the respondents were employed at the time of the survey. The largest group $(27 \%, \mathrm{n}=34)$ of them were working in the field of non-tertiary adult education. The other two major sectors were universities $(23 \%, \mathrm{n}=29)$ and vocational education 
$(20 \%, \mathrm{n}=26)$. Most of the respondents reported that they worked in one sector only, although some mentioned working in several ones. The most common job title among the respondents was teacher $(32 \%, \mathrm{n}=40)$, which comprised various types of job contracts. Typically, the respondents worked as full-time teachers on fixed-term contracts. The amounts of teaching per week varied. Most of the respondents $(90 \%, \mathrm{n}$ $=113)$ had some teaching experience, with $37 \%(n=47)$ having had considerable experience $(\geq 5.5$ years $)$. However, $9 \%(n=11)$ of the respondents had no previous teaching experience. The overall spectrum of the respondents' work fields was diverse, ranging from teaching and guidance to marketing and financial management (cf. Pakkanen 2006.)

\section{Findings}

This study focused on adult educators' conceptions of teachership in light of a set of questionnaire data. Their answers to an open-ended item revealed a variety of conceptions of teaching and of themselves as teachers. Three main categories of conceptions (Table 1) were identified: 1) teachership as an activity, 2) teachership as a personal disposition, and 3) teachership as a process. The three categories illustrate different orientations to teaching and teachership.

[Insert Table 1 here]

\section{Teachership as an Activity}

In most of the descriptions, the respondents considered their teachership through their own activity $(\mathrm{n}=93)$, that is, how one personally works or should work as a teacher in practice. In approaching teachership from the point of view of activity, some 
participants described the pedagogical methods that they used as teachers $(n=38)$, while others wrote about their role in the teaching and learning process $(n=46)$. In the rest of the answers $(\mathrm{n}=9)$ in this category, activity was described in more general terms and underlining the importance of interaction.

A shared feature in all of the responses was a strong emphasis on interaction, either with students and teacher colleagues or with cooperation partners (e.g. within practical training institutions). Thus, the respondents highlighted the social aspect of teacher identity, where meaningful interactions constitute the heart of one's identity formation (see Schepens, Aelterman \& Keer 2007). Consequently, the pedagogical methods mentioned were aimed at giving students a more active role. Several methods were mentioned, such as group work and discussions, dialogue, narrative methods, and problem-based learning. In using these methods the respondents underlined the importance of mutual respect and reciprocity, as in the following quotation:

'In trying to be as competent an expert as possible in my own field as an adult educator, I realise that the students are also competent in many ways. Dialogic and narrative approaches are useful tools.' (R175)

Because interaction with students was strongly emphasised, the respondents saw themselves as facilitators rather than traditional teachers. Instead of using the term 'teacher', they portrayed themselves as tutors, coaches, supporters, inspirers, or colearners. Hence, the importance of student-centredness was highlighted: the respondents stressed the fact that knowledge is constructed by students, supported by the teacher, who is a facilitator of the learning process. One respondent explained the matter as follows: 
'I see myself rather as a guide to learning, that is, I seek to give students an active role. The concept of teacher as drillmaster with a pile of transparencies is not for me.' (R156)

The respondents also highlighted dialogical ways of teaching, that is, teaching methods based on equal and collaborative interaction and listening to other actors in the learning process. One respondent expressed this in the following way:

'I'm like a guide walking beside the student, I support investigative learning, so I see myself as a facilitator of learning, I steer learning. Another thing I consider important is the realisation of collaboration.'

Overall, the teaching conceptions of the respondents were student-centred; teaching was seen as a practice that should promote understanding and conceptual change on the part of students (see Kember 1997; Murray \& Macdonald 1997). The respondents stressed the importance of interaction in their pedagogical methods and in their role in the learning process.

The notions of student-centredness and dialogical ways of teaching also emerged when the respondents characterised their ideals of teaching, i.e. what they try to achieve in their work. One respondent elaborated her aim in teaching as follows:

'My ideal of teaching is to do it so that it could lead to some kind of shared problem-solving process with the students.' (R159)

It seems that the respondents had reflected on their teaching conceptions during the PSAE programme, as their ideal conceptions resembled their actual experiences (cf. Samuelowicz \& Bain 1992; Entwistle \& Walker 2000). 
Teachership as an activity was approached either through pedagogical methods or through one's own role in the teaching/learning process. These two viewpoints shared the same goal of activating the students, and thus they were closely interwoven with each other. For the respondents in our study, this goal meant acknowledging their prior learning experiences as a basis for in-depth learning. They appeared to have internalised the notion of the teacher as an encourager and supporter rather than a deliverer of information. Thus, the respondents' teaching conceptions focused on the facilitation of students' learning and understanding (see e.g. Kember 1997; Murray \& Macdonald 1997).

\section{Teachership as a Personal Disposition}

Teaching has traditionally been understood as a vocation with a strong connection to the individual characteristics of a person, that is, as a way of life rather than just an occupation. This was the case in our data as well. The responses in this category $(\mathrm{n}=$ 18) described teachership as a natural part of one's personality, as manifesting a passion and love for teaching. For some of the participants, teachership appeared as a normal form of self-expression and, more broadly, as a way of life. In the descriptions, teacher identity was strongly connected to identity more generally, as can be noted in the following quotation:

'Deep down I am a teacher in my soul no matter what job I do. For me it's a mission greater than life, a channel through which to express myself, to exist.' (R9)

Besides in terms of personal identity, the respondents described their teachership through their personal characteristics. Adjectives such as 'sympathetic', 
'knowledgeable', 'emotional', 'human-centred', and 'sensitive' were repeated in the answers. These highlighted the emotional (cf. Eteläpelto \& Vakiala 2004) and moral (cf. ten Dam \& Blom 2006) aspects of teacher identity. However, at the same time, some of the participants questioned the relationship between professional and personal identity, suggesting that a strong association or similarity between them is not always desirable. One respondent wrote:

'I'm too strongly directed by my feelings - even in work situations my professional self remains in the shadow of my private self.' (R44) The personal qualities which embodied teachership were mostly related to social interaction with the students. A good teacher was described as a person who truly listens, understands, and interacts with a student (cf. Kember 1997; Murray \& Macdonald 1997). These requirements are consistent with the descriptions of teachership as an activity.

The respondents also considered that expertise in the subject is essential in teaching. Some of the respondents $(n=11)$ referred to the importance of knowing one's subject well enough, and willingness to update one's expertise when needed. One informant mentioned that 'having factual knowledge is also important, although knowledge should be regarded as relative and viewed critically' (R50). A few respondents $(n=4)$ wrote that pedagogical awareness is a crucial element of teacher's expertise, and that at its best, expertise in the subject can promote pedagogical awareness. For example, one respondent put it like this:

'Adequate mastery of one's own subject provides resources for the actual teaching situation as regards adjusting the form/method of teaching, and for development.' (R187) 
This personal dimension of teachership emphasised the fact that, in addition to interaction and student-teacher relationships, the respondents saw teaching as an individual-bounded activity, manifesting personal characteristics and expertise. It is true that also in this case the personal/individual dimension of teacher identity was constructed with reference to various external phenomena. These included relating one's own personal characteristics to colleagues' and students' ideas about what a teacher should be, and taking these into consideration in reflecting on one's own teachership (see Brookfield 1995; Freese 2006). Yet overall, the notion of teachership as a personal ability underlines the central role of subjectivity in professional identity construction. Following the notion of active agency, this subjectivity offers more space for individuality, and for the integration of work with other life domains as a whole (see Flores \& Day 2006; Eteläpelto \& Vakiala 2004).

\section{Teachership as a Process}

The respondents characterised their teachership as something that is never finished but constantly under construction (see Beijaard, Verloop \& Vermunt 2000). They described their teachership, for example, through the metaphors of a journey, underlining thereby the importance of development and change in the construction of their teacher identity. Accordingly, teachership was described as a progressive, transformative, unfinished and uncertain process, through which one's work identity is developed. Many respondents described teaching as progressive $(n=24)$ and emphasised their own active role in developing their teacher identity and expertise through co-operation with colleagues and students. One respondent wrote the following: 
Those respondents who stressed the transformative nature of teaching $(\mathrm{n}=8)$ included the element of change as something inherent within their own teachership. Typically, the informants viewed the conceptions of teaching and teachership as 'changing all the time' (R101), or noted that their own teachership was 'in a state of constant change' (R161). They underlined the fact that teaching cannot be viewed as a stable activity, since transformations of one's own conceptions of teachership form the basis of teacher identity. Some of the respondents described their teachership as unfinished $(\mathrm{n}=11)$, which they see primarily as a normal and positive feature of their professional growth. For example, one respondent wrote:

'Anyway, my own teachership is still taking shape, not in any problematic sense but as a positive challenge and opportunity.' (R84)

On the other hand, some respondents regarded the unfinished nature of teachership as a negative element. They pointed out that this uncertainty caused insecurity as regards how they understood teaching and constructed their teacher identity. This was clearly illustrated in the following quotation:

'For me, being a teacher is perhaps 'a necessary evil'. Since my PSAE I have had to teach without having the time to develop my teaching the way I would have liked. This will lead to unsatisfactory teachership in terms of professional ethics. Reflections within PSAE have been largely forgotten ... my own teachership - what would be a truly natural way of teaching for me personally - is thus still quite an enigma.' (R49)

Altogether, it seems that the unfinished nature of teachership was primarily perceived as an inherent and ordinary part of the development of teacher identity (see 
Lasky 2005; Flores \& Day 2006). However, some respondents were uncomfortable with this, especially with regard to the early stages of their teaching careers.

\section{Discussion and Conclusions}

We investigated Finnish adult educator graduates' conceptions of teachership after the Pedagogical Studies for Adult Educators (PSAE), which is a one-year higher education programme. Our findings revealed three categories of conceptions, which are in line with Davey's (2013) analysis of teacher identities. First of all, the respondents perceived their own teachership through their own activity, that is, how they worked or ought to work as teachers in practice. Secondly, they described teachership as a personal disposition, highlighting individual characteristics, and/or their passion and love for teaching. Thirdly, they characterised their teachership as an ongoing process; as something that is never finished but constantly under (re)construction.

\section{Constructing Teacher Identity in a Teacher Education Programme}

Our study supports the suggestion by Beijaard and colleagues (2004) that in studying teacher identity it is essential to focus on the interplay between the personal and the social. This interplay became visible in several ways in our data. In the first place, the respondents' descriptions of their teachership as an activity indicated the importance of interaction and of the role of the teacher as a facilitator of students' learning. The teacher is an active and personal agent in building relationships with students and colleagues, and through his/her own pedagogical choices, the teacher can affect student learning processes (see ten Dam \& Blom 2006). Secondly, by approaching teachership from the point of view of personality, the respondents underlined the importance of past and present personal experience in relation to their identity at work (see Flores \& 
Day 2006). Thirdly, the importance of subjectivity was visible in the descriptions of teachership as a professional learning process, covering both individual and collective aspects of identity construction. This interplay was seen as manifest in the context of contemporary changes in the world of work, and in the reality of teaching in practice. The conceptions of teachership were also described through feelings and emotions. This would suggest that emotions, as an element of subjectivity, play a central role in teachers' identity constructions (see Darby 2008).

Similarly to the findings by Maaranen and colleagues (2016), the conceptions of teachership identified in this study reflect the idealistic notions of a 'good teacher'. This was especially visible in the conceptions highlighting the personal dispositions. Nevertheless, in spite of the emphasis on the importance of personality and subjectivity in teacher identity construction, the social context was also considered to be an important factor. Although the respondents were working in various fields, they similarly emphasised the pivotal role of interaction with colleagues and of active participation in their working communities, whatever the educational setting (see Billett \& Somerville 2004; Vähäsantanen \& Billet 2008).

In this connection, a factor that needs to be taken into account is the wide spectrum of work tasks reported by our respondents. This diversity is actually one form of contextuality, which affects the conceptions of teaching and teachership. Nevertheless, diversity in adult educators' work is a fact of life today; indeed, it is part and parcel of the multiple contexts that give rise to the complex identity construction of teachers in the field of adult education.

Altogether, the findings support our notion of teachership. Thus, we see conceptions of teaching and of oneself as a teacher as forming of the core elements of 
teachership and teacher identity - an identity that will be further developed and negotiated situationally within work communities.

According to the studied sample of PSAE graduates, teaching is, ideally and at its core, student-centred and dialogical, and involves a sufficient level of expertise in the subject taught. It is obvious that the conceptions revealed in this study have been strongly affected by the training programme and its philosophy. Many of the respondents referred to the PSAE training as a meaningful experience in constructing their professional identity. This was the case not only among the participants who were novice teachers, but also among the trainees with a longer teaching experience. Thus, one important aspect of a teacher training programme is that it gives time and space to reconstruct and reconsider one's teacher identity, in the company of professionals, researchers (academics), and colleagues (see also Darby 2008; Vähäsantanen et al. 2017).

\section{Methodological Limitations and Future Challenges}

The study reported here was part of a larger research programme, and has certain methodological limitations, mainly in relation to the research design, the quality of the data and transferability of the results.

The research design and the data collection method chosen for the larger research project was that of a survey questionnaire. For the purposes of the present study, we used response data from an open-ended item in the questionnaire. In this item the PSAE graduates described their own teachership. Further, these conceptions of teachership were understood to form one part of the professional identity construction of adult education teachers. 
Due to the multifaceted nature of the phenomenon, the main data collection method most often applied in the research of professional identity is qualitative interview. Since this was not a possible choice in this study, the quality of the data can be considered here by its adequacy and relevance. The main indicator of adequacy is saturation. This is an important feature in qualitative research, but it is also applicable to quantitative research, especially in studies where open-ended questions are used. Altogether 126 out of 136 respondents answered the question concerning their teachership. The use of written language responses, and the space allowed for the responses, set certain limitations to how broadly and richly the respondent's views could be expressed. Nonetheless, we considered that there were sufficient grounds to view the varied and multifarious responses provided as meeting the criteria for saturation.

The relevance of the data relates to the selection of the participants. The questionnaire was sent to all students who had completed PSAE training during the years 2002-2004. Although the respondents' backgrounds varied - some having long experience as adult educators and others lacking any prior experience - the PSAE training programme appeared to have resulted in broadly similar ways of thinking, as evidenced by our findings as well.

In the context of our study the transferability of the findings refers to the extent to which the results illustrate teacher identity among adult educators in general. Given that the findings in our study match those of previous studies, we would expect the results to be transferable to other settings as well. However, since all the respondents had completed the same training programme, which would tend to induce similar ways of thinking about teachership, one cannot be sure that the findings reflect more widely 
adult educators' views on the construction of teacher identity. Despite these limitations, we can argue that the conceptions and constructions expressed by the respondents in this study reflect at least partly the Finnish pedagogical principles of teaching and learning that had been adopted and emphasised at the time of the study. An interesting follow-up study would involve research on the PSAE graduates-and their processes of teacher identity construction - as they engage in or continue teaching as professionals in the field of adult education.

The challenges for future research lie in both methodological and theoretical issues. In order to study with greater precision the possible differences between ideal and actual professional identities, a more in-depth qualitative approach (e.g. open interviews) should be applied. Fruitful insights into the process of teacher identity (re)construction might be gained by ethnographic methods, for example, via multimethod strategies focusing on the teaching practices of adult educators on an everyday basis. A longitudinal study on professional identity (re)construction over life courses and individual careers would also be helpful in refining the core elements of adult educators' professional identity. 


\section{References}

Arvaja, M. 2018. “Tensions and Striving for Coherence in an Academic's Professional Identity Work.” Teaching in Higher Education 24 (3): 291-306. doi: 10.1080/13562517.2017.1379483.

Beijaard, D., P .C. Meijer, and N. Verloop. 2004. "Reconsidering Research on Teachers' Professional Identity.” Teaching and Teacher Education 20 (2): 107-128. doi: https://doi.org/10.1016/j.tate.2003.07.001

Beijaard, D., N. Verloop, and J.D. Vermunt. 2000. “Teachers' Perceptions of Professional Identity: an Exploratory Study from a Personal Knowledge Perspective." Teaching and Teacher Education 16 (7): 749-764. doi: https://doi.org/10.1016/S0742-051X(00)00023-8

Billett, S., C. Harteis, and A. Eteläpelto, eds. 2008. Emerging Perspectives of Workplace Learning. Rotterdam: Sense.

Billett, S., and M. Somerville. 2004. "Transformations at Work: Identity and Learning." Studies in Continuing Education 26 (2): 309-326. doi: https://doi.org/10.1080/158037042000225272

Braun, V., and V. Clarke. 2006. "Using Thematic Analysis in Psychology."

Qualitative Research in Psychology 3 (2): 77-101. doi:

https://doi.org/10.1191/1478088706qp063oa

Brehony, K. J. \& Deem, R. 2005. “Challenging the Post-Fordist/Flexible Organisation Thesis: the Case of Reformed Educational Organisations." British Journal of Sociology of Education 26 (3): 395-414. doi: https://doi.org/10.1080/01425690500128924

Brookfield, S. D. 1995. Becoming a Critically Reflective Teacher. San Francisco (CA.): Jossey-Bass.

Darby, A. 2008. “Teachers' Emotions in the Reconstruction of Professional Selfunderstanding." Teaching and Teacher Education 24 (5): 1160-1172. doi: https://doi.org/10.1016/j.tate.2007.02.001

Davey, R. 2013. The Professional Identity of Teacher Educators: Career on the Cusp? London: Routledge. 
Entwistle, N., and P. Walker. 2000. "Strategic Alertness and Expanded Awareness within Sophisticated Conceptions of Teaching." Instructional Science 28 (5): 335-361. doi: https://doi.org/10.1023/A:1026579005505

Eteläpelto, A., K. Vähäsantanen, P. Hökkä, and S. Paloniemi. 2013.’What is Agency? Conceptualizing Professional Agency at Work". Educational Research Review 10: 45-65. doi: doi:10.1016/j.edurev.2013.05.001

Eteläpelto, A., K. Vähäsantanen, P. Hökkä, and S. Paloniemi. 2014. "Identity and Agency in Professional Learning." In International Handbook of Research in Professional and Practice-Based Learning, edited by S. Billett, C. Harteis, and H. Gruber, 645-672. Springer: Dordrecht.

Eteläpelto, A., and V. Vakiala. 2004. "Constructing a Professional Identity of Teachership through Participation in an Authentic Work Context." Proceedings of the Second European Conference of EARLI-SIG Learning and Professional Development, October 11-15, 2004. Regensburg.

Flores, M. A., and C. Day, C. 2006. "Contexts Which Shape and Reshape New Teachers' Identities: A Multi-Perspective Study." Teaching and Teacher Education 22 (2): 219-232. doi: https://doi.org/10.1016/j.tate.2005.09.002

Freese, A. R. 2006. 'Reframing One's Teaching: Discovering Our Teacher Selves through Reflection and Inquiry." Teaching and Teacher Education 22 (1): 100119. doi: https://doi.org/10.1016/j.tate.2005.07.003

Green, A. 2002. "The Many Faces of Lifelong Learning: Recent Education Policy Trends in Europe." Journal of Education Policy 17 (6): 611-626. doi: $10.1080 / 0268093022000032274$

Hökkä, P., K. Vähäsantanen, and S. Mahlakaarto. 2017. 'Teacher Educators' Collective Professional Agency and Identity - Transforming Marginality to Strength." Teaching and Teacher Education 63: 36-46. doi: https://doi.org/10.1016/j.tate.2016.12.001

Kember, D. A 1997. "Reconceptualisation of the Research into University Academics' Conceptions of Teaching." Learning and Instruction 7 (3): 255-275. doi: https://doi.org/10.1016/S0959-4752(96)00028-X

Ketelaar, E., D. Beijaard, H.P.A. Boshuizen, and J. den Brok 2012. “Teachers' Positioning towards an Educational Innovation in the Light of Ownership, 
Sense-making and Agency." Teaching and Teacher Education 28 (2): 273282. doi: https://doi.org/10.1016/j.tate.2011.10.004

Lasky, S. 2005. “A Sociocultural Approach to Understanding Teacher Identity, Agency and Professional Vulnerability in a Context of Secondary School Reform." Teaching and Teacher Education 21 (8): 899-916. doi: https://doi.org/10.1016/j.tate.2005.06.003

Leshem, S. 2008. "Novices and Veterans Journeying into Real-World Teaching: How a Veteran Learns From Novices." Teaching and Teacher Education 24 (1): 204-215. doi: https://doi.org/10.1016/j.tate.2006.07.010

Livingston, K. 2017. "The Complexity of Learning and Teaching: Challenges for Teacher Education.” European Journal of Teacher Education 40 (2): 141-143. doi: https://doi.org/10.1080/02619768.2017.1296535

Maaranen, K., H. Pitkäniemi, K. Stenberg, and L. Karlsson. 2016. ”An Idealistic View of Teaching: Teacher Students' Personal Practical Theories." Journal of Education for Teaching 42 (1): 80-92. doi: https://doi.org/10.1080/02607476.2015.1135278

Murray, K., and R. Macdonald. 1997. "The Disjunction between Lecturers' Conceptions of Teaching and Their Claimed Educational Practice." Higher Education 33 (3): 331-349. doi: https://doi.org/10.1023/A:1002931104852

Pakkanen, M. 2006. "Aikuiskouluttajan työ. Aikuiskouluttajan pedagogisista opinnoista valmistuneiden ajatuksia työstään ja koulutuksestaan. ” [Adult Educators' Work. Adult Educator graduates' Conceptions of Their Work and Training.] Koulutuksen tutkimuslaitos. Työpapereita 25.

Rajala, A. and K. Kumpulainen. 2017. 'Researching Teachers' Agentic Orientations to Educational Change in Finnish Schools." In Agency at Work - An Agentic Perspective on Professional Learning and Development, edited by M. Goller \& S. Paloniemi, 311-329. Dordrecht: Springer.

Ruohotie-Lyhty, M., and J. Moate. 2016. "Who and How? Preservice Teachers as Active Agents Developing Professional Identities." Teaching and Teacher Education 55: 318-327. doi: https://doi.org/10.1016/j.tate.2016.01.022 
Samuelowicz, K., and J. D. Bain. 1992. "Conceptions of Teaching Held by Academic Teachers." Higher Education 24 (1): 93-111. doi:

https://doi.org/10.1007/BF00138620

Samuelowicz, K., and J. D. Bain. 2001. "Revisiting Academics' Beliefs about Teaching and Learning." Higher Education 41 (3): 299-325. doi: https://doi.org/10.1023/A:1004130031247

Schepens, A., A. Aelterman, and H. Van Keer. 2007. "Studying Learning Processes of Student Teachers with Stimulated Recall Interviews through Changes in Interactive Cognitions." Teaching and Teacher Education 23 (4):

457-472. doi: https://doi.org/10.1016/j.tate.2006.12.014

Siivonen, P., Komulainen, K., Räty, H., Korhonen, M., Kasanen, K. \& Rautiainen, R. 2016. "Salvation or a Broken Promise? Two Adult Graduates' Social Positioning in Education and Working Life." Scandinavian Journal of Educational Research 60 (1): 110-125. doi: https://doi.org/10.1080/00313831.2015.1017839

Talbert, J. E., and M. W. McLaughlin. 1996. “Teacher Professionalism in Local School Contexts." In Teachers' Professional Lives, edited by I. Goodson, and A. Hargreaves, 127-153. Falmer Press: London.

ten Dam, G. T. M., and S. Blom. 2006. "Learning through Participation. The Potential of School-Based Teacher Education for Developing a Professional Identity." Teaching and Teacher Education 22 (6): 647-660. doi: https://doi.org/10.1016/j.tate.2006.03.003

Toom, A., K. Pyhältö, and F. Rust. 2015. “Guest Editorial. Teachers’ Professional Agency in Contradictory Times." Teachers and Teaching: Theory and Practice. 21 (6): 615-623. doi: https://doi.org/10.1080/13540602.2015.1044334

Trigwell, K., E. Martin, J. Benjamin, and M. Prosser. 2000. "Scholarship of Teaching: a Model." Higher Education Research and Development 19 (2): 155-168. doi: https://doi.org/10.1080/072943600445628

Trigwell, K., M. Prosser, and F. Waterhouse. 1999. "Relations between Teachers' Approaches to Teaching and Students' Approaches to Learning.” Higher Education 37 (1): 57-70. doi: https://doi.org/10.1023/A:1003548313194 
van den Berg, R. 2002. “Teachers' Meanings Regarding Educational Practice.” Review of Educational Research 72 (4): 577-625. doi:

https://doi.org/10.3102/00346543072004577

Vähäsantanen, K. 2015. "Professional Agency in the Stream of Change:

Understanding Educational Change and Teachers' Professional Identities.”

Teaching and Teacher Education 47: 1-12. doi:

https://doi.org/10.1016/j.tate.2014.11.006

Vähäsantanen, K. and S. Billett. 2008. "Negotiating Professional Identity. Vocational Teachers' Personal Strategies in a Reform Context.” In Emerging Perspectives of Workplace Learning, edited by S. Billett, C. Harteis \& A. Eteläpelto, 35-49. Rotterdam: Sense.

Vähäsantanen, K., P. Hökkä, S. Paloniemi, S. Herranen, and A. Eteläpelto. 2017.

"Professional Learning and Agency in an Identity Coaching Programme."

Professional Development in Education 43 (4): 514-536. doi:

doi:10.1080/19415257.2016.1231131

Wall, C.R.G. 2016. "From Student to Teacher: Changes in Preservice Teacher Educational Beliefs throughout the Learning-To-Teach Journey." Teacher Development 20 (3): 364-379. doi:

https://doi.org/10.1080/13664530.2016.1149509

Wenger, E. 1998. Communities of Practice. Learning, Meaning, and Identity.

Cambridge: Cambridge University Press. 
Table 1. Conceptions of teachership indicated by the respondents (with number of references)

\begin{tabular}{|c|c|c|}
\hline \multicolumn{3}{|l|}{ Teachership as a(n) } \\
\hline Activity (93) & Personal disposition (33) & Process (43) \\
\hline $\begin{array}{l}\text { - Role in teaching and learning } \\
\text { (46) }\end{array}$ & - Part of personality (18) & - Progressive (24) \\
\hline - Used teaching methods (38) & - Expertise of content (11) & - Unfinished (11) \\
\hline - Interaction (9) & - Pedagogical awareness (4) & - Transformative (8) \\
\hline
\end{tabular}

